\title{
ANTISIPASI DINDING PENAHAN TANAH DAERAH PANGKALAN KM 16 KABUPATEN LIMA PULUH KOTA
}

\section{ANTICIPATION OF SOIL DETAINING WALLS ON LAND \\ WATER LEVELS BASED IN KM 16 PANGKALAN LIMA PULUH KOTA REGENCY}

\author{
Hanifah Asnur ${ }^{1}$ dan Dilson ${ }^{2}$ \\ ${ }^{1}$ Sekolah Tinggi Teknologi Payakumbuh \\ Jln. Khatib Sulaiman Sawah Padang Telp. (0752) 796063 HP: 085264570170 \\ Email: hanifasya76@gmail.com \\ ${ }^{2}$ Sekolah Tinggi Teknologi Payakumbuh \\ Jln. Khatib Sulaiman Sawah Padang Telp. (0752) 796063 HP: 082385079499 \\ Email: dilsonpyk2013@gmail.com
}

Naskah Masuk: 14-10-2019

Naskah Diterima: 5-12-2019

Naskah Disetujui: 10-12-2019

\begin{abstract}
The Ground of water content in the Pangkalan area if the level achives more than 50\% (watery or wet soil), the soil becomes watery and wet. it will get its saturation point and wil cause landslide. The purpose of this study was to overcome the occurrence of landslides / slope collapse in Pangkalan, using the Cantilever detaining wall method. Soil samples were taken at base points 10, 16 and 22 by using handboards. Laboratory tests, conducted in Andalas university Laboratory, were carried out to determine water content, atterberg limits, volume weight $(\gamma)$, and direct share (c and $\varphi)$. The data were processed_by entering the parameters of the test results into the calculation of Cantilever detaining wall. The results showed that the soil detaining wall increased the value of the safety factor of the rolling slope which was 3.72; the safety factor for sliding was 2,4 and the safety factor for carrying capacity was 34,89. Further research can also be carried out in anticipating detaining walls at base point KM in Pangkalan Lima Puluh Kota Regency.
\end{abstract}

Keywords : Soil, Moisture content, Landslides, Cantilever Retaining Walls

\begin{abstract}
ABSTRAK
Kadar air tanah daerah pangkalan apabila melebihi $>50 \%$ (tanah encer atau basah)hal tersebut dapat menyebabkan tanah berada pada titik jenuh dan rawan longsor. Tujuan penelitian adalah untuk mengantisipasi terjadinya longsor berdasarkan kadar air tanah pada pangkalan 16 titik 2, mengunakan metode dinding penahan tanah kantilever. Penelitian dilakukan dengan mengambil sample tanah dititik pangkalan 10, 16 dan 22 menggunakan bor tangan. Sampel tanah diuji dilaboratorium Universidas Andalas Padang untuk mendapatkan kadar air tanah asli,kadar air pada batas atterberg limit, berat volume (૪) , dan direct share (c dan $\varphi$ ).Data diolah dengan memasukan parameter-parameter hasil pengujiankedalam perhitungan dinding penahan tanah kantilever.Hasil penelitian menunjukkan dengan adanya dinding penahan tanah dapat meningkatkan nilai faktor keamanan lereng terhadap guling sebesar 3.72, faktor keamanan terhadap geser sebesar 2.4, dan faktor keamanan terhadap daya dukung sebesar 34.89. Penelitian selanjutnya juga dapat dilakukan antisipasi dinding penahan tanah pada titik $\mathrm{Km}$ lainnya di daerah pangkalan kabupaten lima puluh kota.
\end{abstract}

Keywords: Tanah, Kadar air, Longsor, Dinding Penahan Tanah kantilever 


\section{PENDAHULUAN}

Daerah Pangkalan Kabupaten

Lima Puluh Kota secara geografis merupakan daerah perbukitan yang menghubungkan antara Provinsi Sumatera Barat dengan Provinsi Riau. Tingginya intensitas hujan didaerah Pangkalan berdampak terhadap tingginya kadar air di dalam tanah, sehingga tanah tidak mampu menampung air dalam porinya (tanah sudah jenuh air) (Wiraga, 2015), pergerakan massa batuan atau tanah sehingga kuat geser tanah menjadi kecil (Winanda RA dan Setyanto, 2017), dan dapat mengakibatkan terjadinya longsor.

Berdasarkan penelitian yang telah dilakukan di daerah Pangkalan Kabupaten Lima Puluh Kota diketahui batas cair dan batas plastis pada lereng bukit berkisar antara 20\% - 50\% (batas aman). Sementara, kadar air di titik pangkalan KM 16 mencapai lebih dari $50 \%$, sehingga bisa mengakibatkan terjadinya longsor. Selain faktor kadar air, tingkat kemiringan lereng juga faktor penyebab longsor (Taufik dan Kurniawan, 2016). Pendapat yang sama juga menurut Rahmad (Rahmad dan Nurman, 2018) parameter-parameter yang digunakan untuk menentukan tingkat kerawanan longsor adalah jenis tanah, kemiringan lahan, curah hujan dan formasi geologi (batuan induk). Untuk mengatasi terjadinya longsor maka perlu dilakukan antisipasi dengan cara membuatkan dinding penahan tanah. Menurut (Hakam, 2016) dinding penahan tanah berfungsi untuk menahan tekanan lateral tanah yang ditimbulkan oleh tanah dibelakang dinding penahan tanah, baik secara vertikal ataupun terhadap kemiringan tertentu. Dalam pekerjaan rekayasa sipil dinding penahan tanah merupakan salah satu konsep perkuatan tanah yang banyak digunakan dan merupakan salah satu alternatif untuk penanganan longsor lanjutan dan kelongsoran jangka panjang (Ramia, 2017).

Sadat dan Isya, (2018) menyebutkan bahwa faktor keamanan lereng di kecamatan Babahrot Kabupaten Aceh Barat Daya berada dibawah persyaratan $\mathrm{fk}>1,5$. Oleh sebab itu perlu perencanaan dinding penahan tanah menggunakan metode kantilever. (Hidayatullah, 2017) menyebutkan bahwa metode Rankine dan Terzaghi dapat digunakan untuk mengetahui aman atau tidaknya dinding penahan tanah terhadap stabilitas daya dukung tanah, kestabilan terhadap guling, dan 
ketahanan terhadap geser. (Khuzaifah, 2019) juga menyatakan bahwa konstruksi dinding penahan harus mampu menahan gaya berupa momen guling, gaya berat sendiri, gaya lateral tanah/air aktif-pasif, gaya gelincir/sliding dan gaya angkat (uplift). Selanjutnya Solehuddin dan Tifani, (2018) menyatakan dinding Kantilever untuk stabilitas guling diperoleh nilai sebesar 2,074, stabilitas geser 2,0016 dan dukung tanah 7,456 sedangkan dimensi dinding penahan tanah tipe kantilever yang aman terhadap stabilitas guling, geser, dan daya dukung diperoleh nilai lebar atas $0,6 \mathrm{~m}$, lebar dasar pondasi sebesar $3 \mathrm{~m}$, dengan tinggi dinding sebesar $2,7 \mathrm{~m}$ dan tebal dasar pondasi $0,25 \mathrm{~m}$.

Berdasarkan latar belakang tersebut diatas, maka tujuan penelitian adalah membuat perencanaan antisipasi dinding penahan tanah berdasarkan kadar air tanah pada KM 16 daerah Pangkalan Kabupaten Lima Puluh Kota menggunakan metode Kantilever, yaitu dengan cara menahan tanah dibelakangnya dengan memanfaatkan berat sendiri dan berat tanah timbunan di atas telapak, sehingga dapat mencegah terjadinya longsor. Semakin berat struktur dinding penahan tanah dan dimensi tapak dibelakangnya, maka semakin besar pula tahanannya. Selain itu, semakin lebar tapak, maka dinding tersebut semakin stabil berdiri.

Dalam penentuan dimensi / geometri dinding kantilever, harus dibuat sedemikian rupa, sehingga memperhatikan kemungkinan dimensi terbaik yang dapat memberikan bentuk efisiensi bahan dan kemudahan pekerjaan. Pada dinding kantilever untuk pengerjaan tapak dinding tanah dibelakang dinding harus disingkirkan terlebih dahulu. Tanah tersebut selanjutnya akan ditimbunkan kembali setelah telapak dan badan dinding selesai dikerjakan.

Beberapa rumus yang dapat digunakan untuk melakukan perhitungan dinding penahan tanah kantilever adalah sebagai berikut :

\section{Tekanan tanah diam}

$$
\begin{aligned}
& P o=P 1+P 2 \\
& P o=K o \cdot H+\frac{1}{2} \cdot \gamma \cdot H^{2} K o \\
& \text { Keterangan: } \\
& P 1 \quad=\text { Luas segi empat (1) } \\
& P 2 \quad=\text { Luas segi empat (2) } \\
& K o \quad=\text { Koefisien tekanan tanah } \\
& \text { dalam keadaan diam } \\
& H \quad=\text { Tinggi } \\
& \gamma \quad=\text { Berat volume }
\end{aligned}
$$

2. Tekanan tanah aktif dan pasif menurut rankine

a. Tekanan tanah aktif $\sigma a=\sigma v \cdot K a-2 c \sqrt{K a}$ dan 


$$
K a=\tan ^{2}\left(45-\frac{\varphi}{2}\right)
$$

b. Tekanan tanah pasif

$$
\begin{aligned}
& \sigma p=\sigma v \cdot K a+2 c \sqrt{K a} \text { dan } \\
& K a=\tan ^{2}\left(45+\frac{\varphi}{2}\right)
\end{aligned}
$$

Perencanaan bentuk dimensi penampang dinding katilever seperti terlihat pada gambar 1 berikut :

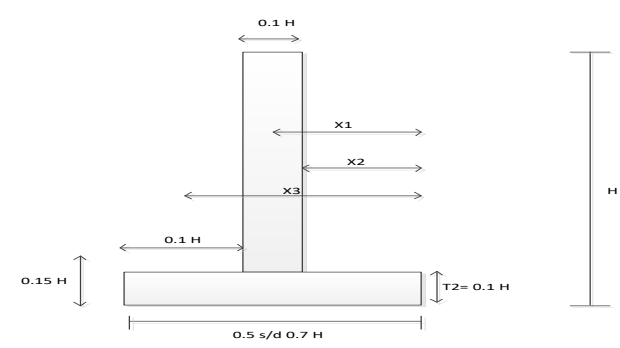

Gambar 1 Dimensi penampang dinding kantilever

Menurut (Nasional, 2017) apabila hasil cek stabilitas tidak memenuhi, berarti dinding penahan tanah tidak aman. Oleh sebab itu harus dilakukan perhitungan ulang terhadap guling (overtuining), geser (sliding), dan daya dukung menggunakan rumus berikut :

\section{Cek terhadap guling (Overtuning)}

$$
S F=\frac{\sum M_{R}}{\sum M_{o}}
$$

Keterangan:

$S F=$ Faktor Keamanan

$M_{R}=$ Momen penahan guling diujung (tumit) dinding

$M_{\circ}=$ Momen Pengguling diujung (tumit) dinding.

\section{Cek terhadap Geser (Sliding)}

$$
S F=\frac{T+P P}{P a}
$$

Keterangan:

$$
\begin{aligned}
& S F=\text { Faktor Keamanan } \\
& T=\text { Tahanan Geser } \\
& P a=\text { Gaya Tekanan Aktif } \\
& P p=\text { Gaya Tekanan Pasif }
\end{aligned}
$$

\section{Cek terhadap daya dukung}

$$
S F=\frac{q u l t}{q \max } \quad \text { qmin }>0.0
$$

Keterangan:

$$
\begin{aligned}
& \text { SF }=\text { Faktor Keamanan } \\
& q u l t=\text { Daya Dukung ultimit } \\
& q \max =\text { Daya Dukung Maximum } \\
& q \min =\text { Daya Dukung Minimum }
\end{aligned}
$$

\section{METODOLOGI}

Penelitian dilakukan pada daerah terbuka lereng bukit di KM 10,16, dan 22 daerah Pangkalan Kabupaten Lima Puluh Kota, pada tanggal 21 November 2017. Pengukuran dilakukan di 3 titik lokasi menggunakan 1 set alat teodolit merek Nikon NE-100, bak ukur, dan meteran seperti terlihat pada gambar 2 . Berikut :

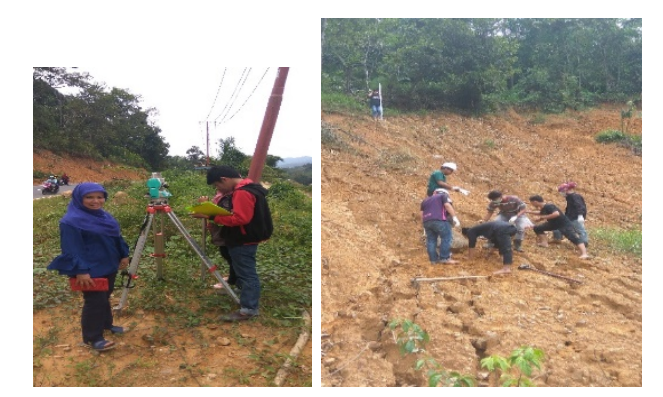

Gambar.2. Pengukuran

Pengukuran dilakukan untuk mencari ketinggian dan sudut kemiringan terhadap lereng pada 3 titik lokasi. Pengambilan sampel dilakukan sebanyak 3 buah ditiap titiknya, yaitu 
bagian atas lereng tanah yang longsor, dibagian bawah lereng tanah yang longsor dan bagian tanah yang tidak mengalami kelongsoran.

Data sample tanah diambil menggunakan tabung sampel berukuran $40 \mathrm{~cm}$ diameter $6.8 \mathrm{~cm}$, martil, balok kayu, palu, linggis, dan plastik dan lainlain berjumlah sebanyak 9 buah tabung sampel tanah.

Pengujian laboratorium dilakukan di Universitas Andalas Padang untuk mendapatkan kadar air tanah asli, kadar air batas atterberg, berat volume, dan direct share.

Perhitungan dinding penahan tanah menggunakan metode kantilever untuk mendapatkan nilai faktor keamanan terhadap guling, geser dan daya dukung tanah. Tahapan yang dilakukan dalam menentukan antisipasi dinding penahan tanah adalah dengan cara merancang dinding penahan tanah, dan melakukan perhitungan menggunakan rumus rankine.

\section{HASIL DAN PEMBAHASAN}

\section{Pengukuran Dilapangan}

Dari hasil pengukuran dilapangan, didapat derajat kemiringan dan ketinggian lereng daerah pangkalan seperti terlihat pada tabel 1:

Tabel 1: Hasil pengukuran dilapangan

\begin{tabular}{ccc}
\hline $\begin{array}{c}\text { Titik Lokasi } \\
\text { Pengujian }\end{array}$ & Kemiringan & Ketinggian \\
\hline $\begin{array}{c}\text { Titik Pangkalan 10 ( } \\
\text { PKL 10) }\end{array}$ & $27^{\circ}$ & $12.1 \mathrm{~m}$ \\
$\begin{array}{c}\text { Titik Pangkalan 16 ( } \\
\text { PKL 16) }\end{array}$ & $30^{\circ}$ & $6.3 \mathrm{~m}$ \\
$\begin{array}{c}\text { Titik Pangkalan 22 ( } \\
\text { PKL 22) }\end{array}$ & $35^{\circ}$ & $10.6 \mathrm{~m}$ \\
\hline Sumber : hasil penelitian & &
\end{tabular}

Tabel 1, menunjukan hasil derajat kemiringan lereng pangkalan 16 titik 2 adalah $30^{\circ}$ dengan ketinggian $6.3 \mathrm{~m}$.

\section{Pengambilan Sample Tanah}

Pengambilan sample tanah ditiga titik lokasi daerah titik pangkalan 10,16 , dan 22 dilakukan pada saat cuaca berada dalam kondisi cerah. Titik lokasi pengambil sampel tanah dapat dilihat pada gambar 3 berikut

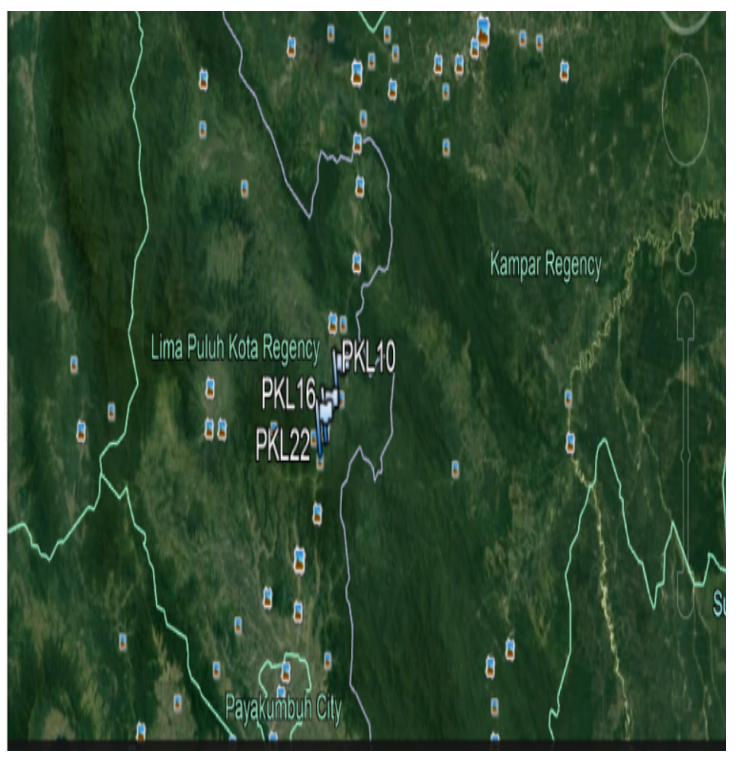

Gambar.3. Peta Titik Sampling 
Data penelitian berupa sampel tanah diambil sebanyak 9 (sembilan) tabung seperti terlihat pada gambar 4

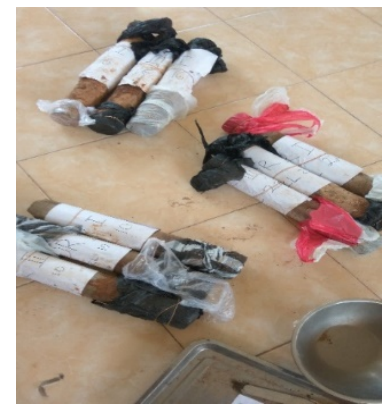

Gambar 4. Sampel Tanah

\section{Pengujian Laboratorium}

Hasil pengujian di laboratorium Mekanika Tanah Universitas Andalas adalah sebagai berikut :

\section{a. Hasil Pengujian Kadar Air}

Hasil pengujian kadar air tanah dapat dilihat pada tabel 2 berikut :

Tabel 2: Hasil pengujian kadar air asli

\begin{tabular}{lc}
\hline & Kadar Air Tanah (\%) \\
\hline PKL 10 Titik 1 & 21.011 \\
PKL 10 Titik 2 & 28.857 \\
PKL 10 Titik 3 & 27.909 \\
PKL 16 Titik 1 & 43.483 \\
PKL 16 Titik 2 & 53.779 \\
PKL 16 Titik 3 & 39.462 \\
PKL 22 Titik 1 & 26.272 \\
PKL 22 Titik 2 & 34.347 \\
PKL 22 Titik 3 & 31.437 \\
\hline Sumber: hasil penelitian & \\
Tabel 2 menunjukkan bahwa hasil \\
pengujian kadar air tanah asli di \\
pangkalan 16 titik 2 50 \%, yaitu \\
53,779\%, artinya kadar air ini melewati \\
kadar air pada batas atterberg limit \\
tanah longsor.
\end{tabular}

\section{b. Pengujian Batas Konsistensi (Batas Atterberg)}

Hasil pengujian batas konsistensi tanah dapat dilihat pada tabel 3 berikut:

Tabel 3: Hasil pengujian atterberg limit

\begin{tabular}{cccc}
\hline \multirow{2}{*}{ Titik Lokasi } & \multicolumn{3}{c}{ Kadar Air Tanah (\%) } \\
\cline { 2 - 4 } & $\begin{array}{c}\text { Liquid } \\
\text { Limit } \\
(\%)\end{array}$ & $\begin{array}{c}\text { Plastic } \\
\text { Limit } \\
(\%)\end{array}$ & $\begin{array}{c}\text { Indeks } \\
\text { Plastis }\end{array}$ \\
\hline PKL 10 Titik 1 & 26.546 & 20.634 & 5.913 \\
PKL 10 Titik 2 & 29.47 & 20.15 & 9.318 \\
PKL 10 Titik 3 & 30.427 & 21.32 & 9.108 \\
PKL 16 Titik 1 & 42.336 & 21.77 & 20.57 \\
PKL 10 Titik 2 & 29.47 & 20.15 & 9.318 \\
PKL 10 Titik 3 & 30.427 & 21.32 & 9.108 \\
PKL 16 Titik 1 & 42.336 & 21.77 & 20.57 \\
PKL 16 Titik 2 & 54.546 & 20.33 & 34.239 \\
PKL 16 Titik 3 & 44.45 & 21.37 & 23.084 \\
PKL 22 Titik 1 & 36.175 & 24.44 & 11.731 \\
PKL 22 Titik 2 & 36.79 & 25 & 11.79 \\
PKL 22 Titik 3 & 42.586 & 22.94 & 19.643 \\
\hline Sumber : hasil penelitian & &
\end{tabular}

Tabel 3 menunjukkan hasil pengujian batas konsistensi (atterberg limit) tanah didapat kadar air tanah di lokasi Pangkalan 16 titik $2>50 \%$ yaitu $54,546 \%$. dan berakibat longsor.

\section{c. Pengujian Berat Volume}

Hasil pengujian berat volume dapat dilihat pada tabel 4 berikut :

Tabel 4: Hasil pengujian berat volume

\begin{tabular}{ll}
\hline \multicolumn{1}{c}{ Titik Lokasi } & \multicolumn{1}{c}{$\begin{array}{c}\text { Berat Volume Tanah } \\
(\mathrm{g} / \mathrm{cm} 3)\end{array}$} \\
\hline PKL 10 Titik 1 & 2.129 \\
PKL 10 Titik 2 & 2.101 \\
PKL 10 Titik 3 & 2.205 \\
PKL 16 Titik 1 & 2.01 \\
PKL 16 Titik 2 & 1.768 \\
PKL 16 Titik 3 & 2.17 \\
PKL 22 Titik 1 & 2.179 \\
PKL 22 Titik 2 & 1.893 \\
PKL 22 Titik 3 & 2.175 \\
\hline
\end{tabular}

Sumber : hasil penelitian 
Tabel 4 menunjukkan hasil pengujian berat volume tanah pada lokasi Pangkalan 16 titik 2 sebesar 1.768 $\left(\mathrm{g} / \mathrm{cm}^{3}\right)$, dan digunakan sebagai salah satu parameter untuk merencanakan dinding penahan tanah.

\section{d. Pengujian Direct Shear}

Hasil pengujian direct shear dapat dilihat pada tabel 5 berikut :

Tabel 5: Hasil pengujian direct shear

\begin{tabular}{lll}
\hline \multicolumn{1}{c}{ Titik Lokasi } & $\begin{array}{l}\text { Direct Shear } \\
\text { c (Kg/cm2) }\end{array}$ & $\phi\left(^{0}\right)$ \\
\hline PKL 10 Titik 1 & 0.126 & 40.103 \\
PKL 10 Titik 2 & 0.094 & 36.386 \\
PKL 10 Titik 3 & 0.108 & 40.103 \\
PKL 16 Titik 1 & 0.173 & 19.336 \\
PKL 16 Titik 2 & 0.126 & 44.495 \\
PKL 16 Titik 3 & 0.168 & 50.031 \\
PKL 22 Titik 1 & 0.075 & 46.471 \\
PKL 22 Titik 2 & 0.117 & 46.471 \\
PKL 22 Titik 3 & 0.136 & 42.376 \\
& & \\
\hline
\end{tabular}

Sumber : hasil penelitian
Tabel 5 menunjukkan hasil uji kekuatan geser langsung (direct shear) pada lokasi pangkalan 16 titik 2 didapat nilai kohesi ( c ) sebesar $0.126(\mathrm{~kg} / \mathrm{cm} 2)$, dan nilai sudut geser $(\varphi)$ dalam sebesar $44.495^{\circ}$ dan merupakan parameter untuk merencanakan dinding penahan tanah.

\section{e. Antisipasi Dinding Penahan Tanah}

1) Rancangan antisipasi dinding penahan tanah

Berdasarkan hasil penelitian pengukuran lapangan, pengujian berat volme dan pengujian Direct Shear di pangkalan 16 titik 2 maka untuk rancangan antisipasi dinding penahan tanah dapat dilihat pada gambar 5 berikut :

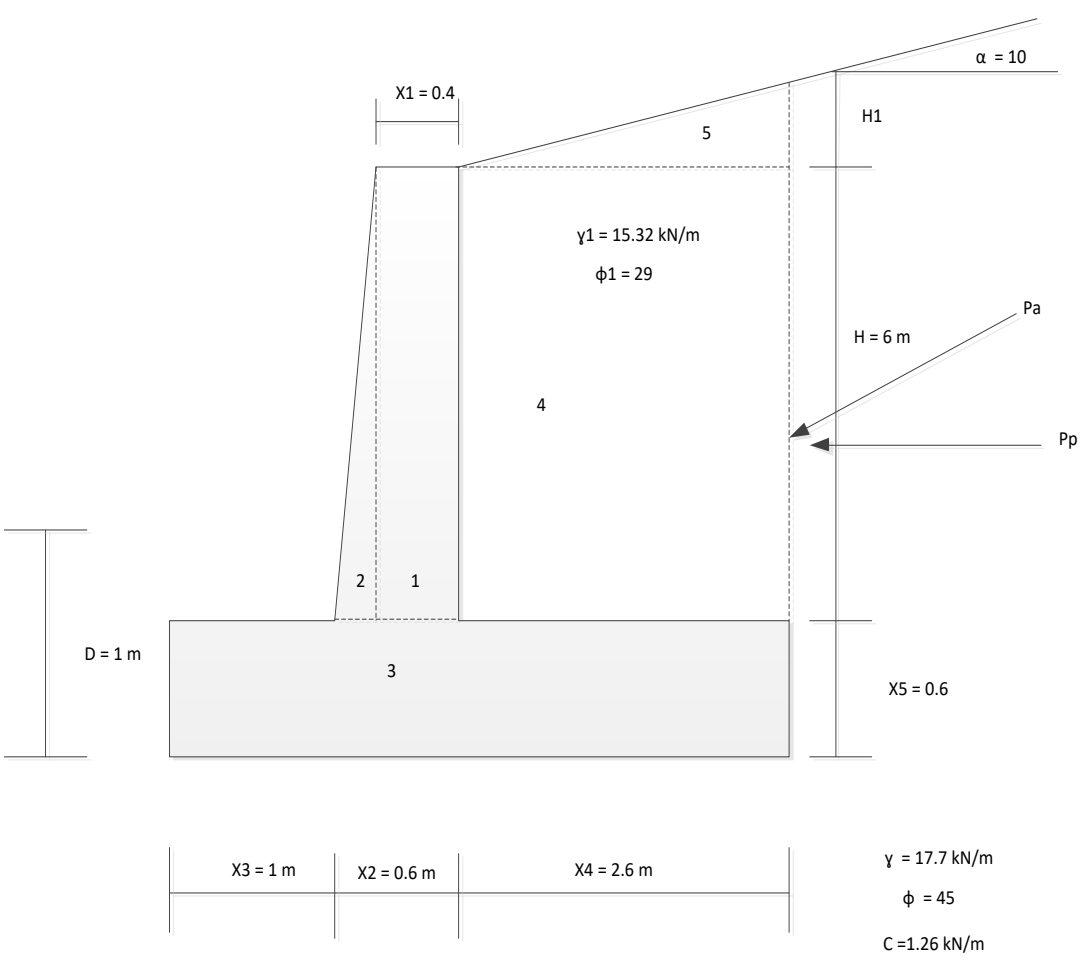

Gambar.5. Rencana rancangan dinding penahan tanah 
Gambar 5. Menunjukan nilai perancangan dinding penahan tanah diambil dari data ketinggian lereng \pm 6 $\mathrm{m}$, , berat volume tanah $(\gamma)=17.68$ $(\mathrm{kN} / \mathrm{m})$, sudut geser dalam $(\varphi)=45$, dan kohesi $(\mathrm{c})=1.26(\mathrm{kN} / \mathrm{m})$ pada pangkalan 16 titik 2

2) Melakukan perhitungan menggunakan rumus rankine,

$$
\begin{aligned}
& \text { H1 }=(\mathrm{x} 4)(\tan \alpha)=(2.6)\left(\tan 10^{\circ}\right) \\
& =0.458 \mathrm{~m} \\
& \mathrm{H}^{\prime}=\mathrm{H} 1+\mathrm{H}+\mathrm{X} 5 \\
& =0.458+6+0.6 \\
& =7.058 \mathrm{~m}
\end{aligned}
$$

(a) Gaya tekan aktif rankine persatuan panjang dinding

$$
K_{\alpha}=\cos \alpha \cdot \frac{\cos \alpha-\sqrt{\cos ^{2} \alpha-\cos ^{2} \phi}}{\cos \alpha+\sqrt{\cos ^{2} \alpha-\cos ^{2} \varphi}}
$$

$$
\begin{gathered}
K_{\alpha}=\cos 10 \cdot \frac{\cos 10-\sqrt{\cos ^{2} 10-\cos ^{2} 29}}{\cos \alpha+\sqrt{\cos ^{2} 10-\cos ^{2} 29}} \\
K_{\alpha} \quad=0.366 \\
P_{\alpha}=1 / 2 K_{a} \gamma_{a} H^{2}=1 / 2(0.366)(15.3)(7.058)^{2}= \\
139.48 \mathrm{kN} / \mathrm{m} \\
P_{h}=P_{h} \cos \alpha=(139.48) \cos 10^{\circ} \\
\quad=137.388 \mathrm{kN} / \mathrm{m} \\
P_{D}=P_{\alpha} \sin \alpha=(139.48) \sin 10^{\circ} \\
=24.269 \mathrm{kN} / \mathrm{m}
\end{gathered}
$$

\begin{tabular}{|c|c|c|c|c|c|}
\hline $\begin{array}{c}\text { Penampa } \\
\text { ng } \\
(1)\end{array}$ & $\begin{array}{c}\text { Luas } \\
\text { Penampang } \\
\text { (2) }\end{array}$ & $\begin{array}{c}\text { Berat/satuan } \\
\text { panjang dinding } \\
(3)=\gamma \times(2)\end{array}$ & $\begin{array}{l}\text { Lengan momen } \\
\text { terhadap titik C } \\
\text { (4) }\end{array}$ & $\begin{array}{l}\text { Momen terhadap titik } \\
C(5)=(4) \times(3)\end{array}$ & $\begin{array}{c}\text { Penampang } \\
\text { (1) }\end{array}$ \\
\hline 1 & 2.4 & 56.59 & 1.4 & 79.23 & 1 \\
\hline 2 & 0.6 & 14.15 & 1.13 & 15.98 & 2 \\
\hline 3 & 2.52 & 59.42 & 2.1 & 124.78 & 3 \\
\hline 4 & 15.6 & 274.56 & 2.9 & 796.224 & 4 \\
\hline \multirow[t]{3}{*}{5} & 1.38 & 24.288 & 3.3 & 80.150 & 5 \\
\hline & & 27.917 & 4.2 & 117.251 & \\
\hline & & $\Sigma \mathrm{V}=456.925$ & & $\Sigma M_{R}=1213.615$ & \\
\hline
\end{tabular}

(b) Faktor keamanan terhadap guling pada Titik C

$$
\mathrm{FS}_{(\text {guling })}=\frac{\sum M_{R}}{\sum M_{0}}
$$

Jadi jumlah momen dari gaya-gaya yang menyebabkan guling di titik c

$\sum M_{0}=P_{h}\left[\frac{H}{3}\right]=(137.388)\left[\frac{7.058}{3}\right]=323.228 \mathrm{kN}-m$

Hasil perhitungan jumlah momen dari gaya yang menahan guling dititik $\mathrm{c}$ dapat dilihat pada tabel 6 berikut :

Table 6: Tabel Perhitungan momen penahan $\Sigma \mathrm{M}_{R}$

Sumber : hasil penelitian

Berdasarkan tabel 6. Nilai dari $\Sigma \mathrm{V}$ $=456.925, \Sigma \mathrm{M}_{\mathrm{R}}=1213.615$ digunakan untuk menghitung faktor keamanan dinding penahan tanah terhadap guling, terhadap geser dan terhadap daya dukung tanah.
Faktor keamanan :

$$
\mathrm{FS}_{\text {(guling) }}=\frac{\sum M_{R}}{\sum M_{0}}=\frac{121 \mathrm{a} .615}{\mathrm{a} 2 \mathrm{a} .22 \mathrm{~s}}=3.75>2
$$

(c) Faktor keamanan terhadap geser.

$$
P_{\mathrm{p}=\frac{1}{2} W_{2} D^{2} K_{p}+2 E_{2} D_{8} \sqrt{K_{D}}}
$$


Dari perhitungan didapat

Dimana :

$$
\begin{aligned}
& K_{p=\tan ^{2}\left(45+\frac{45}{2}\right)=5.92} \\
& D=1 \mathrm{~m} \\
& V_{2=17.68 \mathrm{kNN} / \mathrm{m}^{3}} \\
& c_{2=1.26 \mathrm{kN} / \mathrm{m}^{2}} \\
& k_{1}=k_{2=2 / 3}
\end{aligned}
$$

Maka

$$
P_{\mathrm{p}=\frac{1}{2}(17.7)(1)^{2}(5.98)+2(1.26)[(1) \sqrt{5.9}}
$$

Faktor keamanan adalah :

$$
\text { FS (Geger) })=\frac{(456.925) \tan \left(\frac{2}{a} \times 45\right)+(4.2)\left(\frac{2}{a}\right.}{\frac{246.587}{197.961}}
$$

(d) Faktor keamanan terhadap

keruntuhan daya dukung

Menentukan nilai eksentrisitas (e) dari resultan gaya $(\mathrm{R})$ :

$$
\begin{aligned}
& e=\frac{B}{2}-\frac{\sqrt{M_{R}-M_{0}}}{\sqrt{V}} \\
& e=\frac{4.2}{2}-\frac{1213.615-323.228}{456.925} \\
& e=2.1-\frac{1213.615-323.228}{456.925} \\
& e=0.151<\frac{B}{6}=\frac{4.2}{6}=0.7 \mathrm{~m}
\end{aligned}
$$

Menentukan $\mathrm{q}_{\text {toe }}$ dan $\mathrm{q}_{\text {heel }}$ :

$$
\begin{aligned}
& \mathrm{q}_{\min }=\mathrm{q}_{\text {heel }}=\frac{\sum V}{B}\left(1 \pm \frac{6 E}{B}\right) \\
& \mathrm{q} \\
& \frac{\sum V}{B}\left(1+\frac{68}{B}\right)=\frac{456.925}{4.2}\left(1+\frac{\text { toe }}{4.2}\right)= \\
& 132.291 \mathrm{kN} / \mathrm{m}^{2}
\end{aligned}
$$$$
\frac{\mathrm{g} V}{B}\left(1-\frac{6 \mathrm{~g}}{B}\right)=\frac{456.925}{4.2}\left(1-\frac{6 \times 0.151}{4.2}\right)=
$$
$85.293 \mathrm{kN} / \mathrm{m}^{2}$ (ultimate) tanah : $\mathrm{q}_{\max }=132.291 \mathrm{kN} / \mathrm{m}^{2}$

Menentukan daya dukung batas

$$
q_{u}=c_{2} N_{c} F_{c d} F_{c i}+q N_{q} F_{q d} F_{q i}+\frac{1}{2} \gamma_{2} N_{Y} F_{Y d} F_{Y i}
$$

Untuk $\varphi_{2=45^{\circ}}$ dari tabel didapat :

$N_{\text {c }=132.87} \quad N_{\text {q }=134.97} N_{Y=262.7}$

$$
\begin{aligned}
& q=\gamma_{2} D=(17.7)(1)=17.7 \mathrm{kN} / \mathrm{m}^{2} \\
& B^{\prime}=B-2 e=4.2-(2)(0.151)=3.898
\end{aligned}
$$$$
F_{c d}=1+0.4 \frac{D}{B^{\prime}}=1+\left(0.4 \times \frac{1}{3.898}\right)=1.103
$$$$
F_{q d}=1+2 \tan \varphi_{2}(1-\sin \varphi)^{2} \frac{D}{B}
$$$$
F_{\text {qd }}=1+2 \tan 45^{\circ}(1-
$$

$$
\left.\sin 45^{\circ}\right)^{2} \frac{1}{\text { a. }}
$$$$
=1.044
$$$$
F_{Y d}=1
$$

$$
\begin{aligned}
& F_{\mathrm{ci}}=F_{q \mathrm{i}}=\left(1-\frac{\psi^{2}}{90^{0}}\right)^{2} \\
& =\left(1-\frac{19}{90^{0}}\right)^{2} \\
& =0.622 \\
& F_{\mathrm{Yi}}=\left(1-\frac{\psi^{2}}{\varphi^{0}}\right)^{2} \\
& =0.334 \\
& \Psi^{0}=\tan ^{-1}\left(\frac{P_{\alpha} \cos \alpha}{\sum V}\right) \\
& \psi^{0}=\tan ^{-1}\left(\frac{139.48 \cos 10}{456.925}\right) \\
& =19^{\circ}
\end{aligned}
$$

Sehingga daya dukung ultimate adalah :

$$
\begin{aligned}
& q_{u}=c_{2} N_{c} F_{c d} F_{c i}+q N_{q} F_{q d} F_{q i}+\frac{1}{2} \gamma_{2} N_{Y} F_{Y d} F_{Y i} \\
& q_{u}=(1.26)(133.87)(0.622)+(17.7)(134.87)(0.622)+\frac{1}{2} \\
& q_{u}=104.917+1484.837+3026.855
\end{aligned}
$$

188 | Jurnal Pembangunan Nagari |Volume 4 Nomor 2 Edisi Desember 2019 : 180 - 192 


$$
q_{u}=4616.609 \mathrm{kN} / \mathrm{m}^{2}
$$

Faktor keamanan terhadap keruntuhan daya dukung adalah :

$$
\begin{aligned}
& F S_{\text {(daya dukung) }}=\frac{q_{u}}{q_{\max }} \\
& =\frac{4616.6}{132.291} \\
& =34.89>3 \ldots \ldots \text { ke }
\end{aligned}
$$

(e) Gaya-gaya yang bekerja pada dinding adalah sebagai berikut :

Tanah Timbunan

$$
\begin{array}{ll}
\gamma 1 & =1.532 \mathrm{t} / \mathrm{m}^{3} \\
\phi 1 & =29^{\circ}
\end{array}
$$

Tanah Asli

$$
\begin{aligned}
& \gamma 2=1.768 \mathrm{t} / \mathrm{m}^{3} \\
& \phi 2=45 \\
& \mathrm{c} 2=0.126 \mathrm{t} / \mathrm{m}
\end{aligned}
$$

Dinding

$$
\begin{aligned}
& \gamma \mathrm{c}=2.4 \mathrm{t} / \mathrm{m}^{3} \\
& \text { Tinggi, } \mathrm{H}=6 \mathrm{~m} \\
& \text { Tebal atas }(\mathrm{T} 1)=0.6 \mathrm{~m} \\
& \text { Tebal bawah }(\mathrm{T} 2)=1 \mathrm{~m} \\
& \text { Lebar }(\mathrm{B})=2.6 \mathrm{~m}
\end{aligned}
$$

(f) Hasil perhitungan gaya-gaya yang bekerja pada dinding:

(1) Gaya tekanan aktif tanah timbunan, $\mathrm{P}$

$$
\begin{aligned}
& P_{a} \gamma=1 / 2 \gamma H^{2} K a \\
& \text { Dengan } \\
& \mathrm{Ka}=\tan ^{2}(45-\phi / 2) \\
& \mathrm{P} 1=\frac{1}{2}(1.532 \mathrm{t} \cdot \mathrm{m} 2)[(1 / 2(5.4 \mathrm{~m})] 2 \\
&(0.366) \\
&= 4.088 \mathrm{t} / \mathrm{m}
\end{aligned}
$$

Garis kerja P1 dari dasar dinding terletak pada :

$$
\begin{aligned}
Y_{1} & =1 / 3 h_{1} \\
& =1 / 3(2.7) \\
& =0.9 \mathrm{~m}
\end{aligned}
$$

Garis kerja Pa dari dasar dinding terletak pada:

$$
\begin{aligned}
\mathrm{Y}_{\mathrm{a}} & =1 / 3 \mathrm{H} \\
& =1 / 3(5.4 \mathrm{~m}) \\
& =1.8 \mathrm{~m}
\end{aligned}
$$

(2) Gaya berat sendiri dinding dan tanah

$$
W_{c}=\gamma_{c}\left(B_{1}\right) T_{2}
$$

(Berat tapak belakang, bentuk persegi)

$$
\begin{aligned}
& =\left(2.4 \mathrm{~m}^{2}\right)(1 \mathrm{~m})(0.6 \mathrm{~m}) \\
& =1.44 \mathrm{t} / \mathrm{m} \\
W_{s} & =\gamma_{c} B_{1}\left(H-T_{2}\right)
\end{aligned}
$$

(Berat tanah diatas tapak, bentuk persegi)

$$
\begin{aligned}
& =\left(2.4 \mathrm{~m}^{2}\right)(1.532 \mathrm{~m})(6 \mathrm{~m}-0.6 \mathrm{~m}) \\
& =9.288 \mathrm{t} / \mathrm{m}
\end{aligned}
$$

Berat total

$$
\begin{aligned}
W & =W c+W s \\
& =1.44 t+9.288 t=10.728 t\left(m^{\prime}\right)
\end{aligned}
$$

Garis kerja titik tapak belakang

$$
\begin{aligned}
\mathrm{x}_{1} & =1 / 2 \mathrm{~B}_{1} \\
& =1 / 2(1 \mathrm{~m}) \\
& =0.5 \mathrm{~m}
\end{aligned}
$$

Garis kerja titik tapak depan

$$
\begin{aligned}
x_{2} & =1 / 2 B 1+T 1 \\
& =1 / 2(1 m)+0.6 m \\
& =1.1 m
\end{aligned}
$$

Untuk badan dinding tegak

$$
\begin{aligned}
& W_{t} \quad=\gamma_{c} T_{1}\left(H-T_{2}\right) x \\
& (\text { Berat badan dinding tegak }) \\
& =\left(2.4 \mathrm{~m}^{2}\right)(0.6 \mathrm{~m})(6 \mathrm{~m}-0.6 \mathrm{~m}) \\
& =7.78 \mathrm{t} / \mathrm{m}
\end{aligned}
$$

Garis kerja terhadap titik kaki depan 


$$
\begin{aligned}
x_{t} & =1 / 2 T_{1} \\
& =1 / 2(0.6 \mathrm{~m}) \\
& =0.3 \mathrm{~m}
\end{aligned}
$$

(3) Daya dukung pondasi Q :

Menggunakan rumus terzaghi dengan anggapan q' $=0$

Untuk

$$
\begin{aligned}
\phi= & 45^{\circ} \\
\mathrm{N}_{\mathrm{c}}= & 133.87 \\
\mathrm{~N} \gamma= & 262.7 \\
\mathrm{q}= & \mathrm{c}_{2} \mathrm{~N}_{\mathrm{c}}+1 / 2 \text { rBN } \gamma \\
= & (0.126)(133.87)+1 / 2 \\
& (1.768)(4.2)(262.7) \\
= & (16.86)+(975.4) \\
= & 992.21 \mathrm{t}\left(\mathrm{m}^{\prime}\right) \\
\mathrm{q}_{\text {izin }}= & 992.21 / 3 \\
= & 330.73 \mathrm{t} /\left(\mathrm{m}^{\prime}\right)
\end{aligned}
$$

Selanjutnya :

$$
\begin{aligned}
Q \quad & =q_{\text {izin }} \times B_{2} \\
& =330.73 \times 2.6 \\
& =859.92 \mathrm{t} /\left(\mathrm{m}^{\prime}\right)
\end{aligned}
$$

(4) Momen pada dinding

$$
\begin{aligned}
& \mathrm{M}_{\mathrm{f}} \quad=\mathrm{P}_{1}\left(\mathrm{y}_{1}\right) \\
& =4.088 \mathrm{t}\left(/ \mathrm{m}^{\prime}\right)(0.9 \mathrm{~m}) \\
& =3.679 \mathrm{t} \cdot \mathrm{m}(/ \mathrm{m}) \\
& \mathrm{M}_{\mathrm{b}} \quad=\mathrm{P}_{\mathrm{a}}\left(\mathrm{y}_{\mathrm{a}}\right) \\
& =4.088 \mathrm{t}\left(/ \mathrm{m}^{\prime}\right)(1.8 \mathrm{~m}) \\
& =7.36 \mathrm{t} \cdot \mathrm{m}(/ \mathrm{m}) \\
& \mathrm{M}_{\mathrm{h}}=\mathrm{W}\left(\mathrm{x}_{1}\right) \\
& =10.728 \mathrm{t}\left(/ \mathrm{m}^{\prime}\right)(0.5 \mathrm{~m}) \\
& =5.364 \mathrm{t} . \mathrm{m}(/ \mathrm{m}) \\
& \mathrm{M}_{\mathrm{t}}=\mathrm{Wx}_{1}+\mathrm{W}_{\mathrm{t}} \mathrm{x}_{\mathrm{t}} \\
& =107.8 \mathrm{t}\left(/ \mathrm{m}^{\prime}\right)(1.1 \mathrm{~m})+7.78 \\
& \mathrm{t}\left(/ \mathrm{m}^{\prime}\right)(0.3 \mathrm{~m}) \\
& =14.134 \mathrm{t} . \mathrm{m}(/ \mathrm{m}) \\
& =859.92 \mathrm{t}\left(/ \mathrm{m}^{\prime}\right)(1 / 2 \quad 2.6 \mathrm{~m}) \\
& =1117.9 \mathrm{t} \cdot \mathrm{m}(/ \mathrm{m})
\end{aligned}
$$

(5) Gaya geser pada dinding

$$
\begin{array}{cc}
\mathrm{T}_{\mathrm{f}} & =\mathrm{P}_{1} \\
& =4.088 \mathrm{t} \cdot \mathrm{m}(/ \mathrm{m}) \\
\mathrm{T}_{\mathrm{b}} & =\mathrm{P}_{\mathrm{a}} \\
& =8.175 \mathrm{t} \cdot \mathrm{m}(/ \mathrm{m}) \\
\mathrm{T}_{\mathrm{h}} & =\mathrm{W} \\
& =10.728 \mathrm{t} \cdot \mathrm{m}(/ \mathrm{m})
\end{array}
$$

$$
\begin{array}{ll}
\mathrm{T}_{\mathrm{t}} & =\mathrm{W} \mathrm{x}_{2}+\mathrm{Wt} \mathrm{x}_{\mathrm{t}} \\
= & 10.728 \mathrm{t} \cdot \mathrm{m}(/ \mathrm{m})+7.78 \mathrm{t} \cdot \mathrm{m}(/ \mathrm{m}) \\
= & 18.508 \mathrm{t} \cdot \mathrm{m}(/ \mathrm{m})
\end{array}
$$

Atau

$$
\mathrm{Q}=859.92 \mathrm{t} \cdot \mathrm{m}(/ \mathrm{m})
$$

(6) Penulangan pada dinding

Gaya geser (per meter dinding)

$$
\begin{aligned}
& T_{f}=4.088 \mathrm{t} \cdot \mathrm{m}(/ \mathrm{m}) \\
& T_{b}=8.175 \mathrm{t} \cdot \mathrm{m}(/ \mathrm{m}) \\
& T_{h}=10.728 \mathrm{t} \cdot \mathrm{m}(/ \mathrm{m}) \\
& T_{t}=18.508 \mathrm{t} \cdot \mathrm{m}(/ \mathrm{m})
\end{aligned}
$$

Untuk Gaya geser (per meter dinding)

$\mathrm{T}_{\mathrm{f}}$ Ketebalan diperlukan sudah oke $\mathrm{T}_{\mathrm{b}}$ Ketebalan diperlukan sudah oke $\mathrm{T}_{\mathrm{h}}$ Ketebalan diperlukan sudah oke $\mathrm{T}_{\mathrm{t}}$ Ketebalan diperlukan sudah oke Momen (per meter dinding)

$$
\begin{array}{ll}
M_{f} & =3.679 t \cdot m(/ m) \\
M_{b} & =7.36 t \cdot m(/ m) \\
M_{h} & =5.364 t\left(/ m^{\prime}\right) \\
M_{t} & =14.134 t \cdot m(/ m)
\end{array}
$$

Dengan memasukan nilai-nilai momen kedalam gambar 5, untuk ketebalan dinding yang bersesuaian, diperoleh jumlah luas tulangan per meter lebar dinding adalah :

Untuk momen (per meter dinding)

$\mathrm{M}_{\mathrm{f}}$ diperlukan luas tulangan 2000 $\left(\mathrm{mm}^{2}\right)$ - Tulangan minimum

$\mathrm{M}_{\mathrm{b}}$ diperlukan luas tulangan 2000 $\left(\mathrm{mm}^{2}\right)$ - Tulangan minimum

$\mathrm{M}_{\mathrm{h}}$ diperlukan luas tulangan 3000 $\left(\mathrm{mm}^{2}\right)$ - Tulangan minimum 
$\mathrm{M}_{\mathrm{t}}$ diperlukan luas tulangan 3000 $\left(\mathrm{mm}^{2}\right)$ - Tulangan minimum

Dengan memasukan nilai-nilai tersebut di atas kedalam tabel, maka diperoleh jumlah tulangan yaitu : 6-D22 (D22250) untuk dinding tegak 8-D22(D22150) untuk dasar dinding (pondasi). Tulangan tekan dan pembagi digunakan $50 \%$ tulangan utama.

Bentuk perkuatan tulangan dinding akhir dapat dilihat pada gambar 6 berikut :

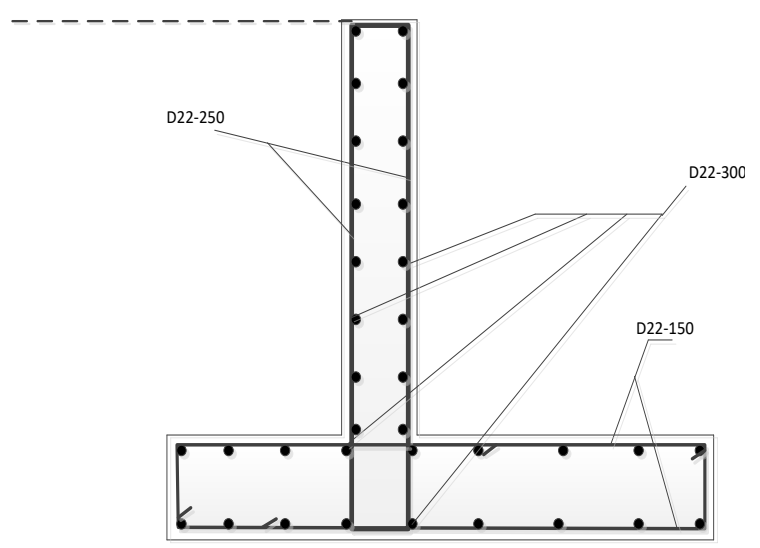

Gambar.6. Perkuatan tulangan dinding

Gambar 6. Menunjukan hasil perhitungan dinding penahan tanah menggunakan tulangan D22-150, D22250 dan D22-300

\section{KESIMPULAN}

Berdasarkan hasil penelitian daerah pangkalan Kabupaten Lima Puluh Kota, kadar air pada batas atterberg limit antara $20 \%$ s/d $50 \%$ (batas aman). Dari nilai tersebut, apabila kadar air tanah berada dibawah nilai batas plastis, maka tanah menjadi tidak kohesif karena kering, dan apabila kadar air tanah berada diatas batas cair, maka tanah menjadi encer. Sesuai dengan hasil penelitian, dari sembilan titik lokasi pengujian hanya satu titik yang berada diluar batas atterberg limit adalah titik pangkalan 16 (PKL 16 Titik 2) dengan nilai kadar air $54.546 \%$ yang sewaktu-waktu akan longsor, oleh sebab itu perlu antisispasi dinding penahan tanah. Hasil perhitungan dinding penahan tanah dengan metode kantilever yaitu faktor keamanan terhadap guling $=3.72$ (aman), faktor keamanan terhadap geser $=2.4$ (aman) dan faktor keamanan terhadap daya dukung $=34.89$ (aman). Selanjutnya perlu juga dilakukan perhitungan gayagaya yang bekerja pada dinding sebagai perkuatan tulangan dinding.

\section{REKOMENDASI}

Sebaiknya penelitian juga dilakukan pada daerah pangkalan di kilometer lainya dan membuat antisipasi dinding penahan tanah di titik-titik daerah yang rawan mengalami kelongsoran. . 
DAFTAR PUSTAKA

Solehuddin dan Tifani, Z. (2018) 'Perencanaan Dinding Penahan Tanah (Studi Kasus: Jalan Lingkar Barat Duri)', in Seminar Nasional Industri dan Teknologi (SNIT), Politeknik Negeri Bengkalis, pp. 397-406.

Kurniawan, A. (2016) 'Identifikasi Daerah Rawan Tanah Longsor Kasus: Kabupaten', Jurnal Teknik ITS, 5(2), pp. $78-82$.

Hakam, A. (2016) 'Dinamis Dinding Penahan Tanah Kantilever Berdasarkan Disain Spektra Kota Padang Panjang', in 20th Annual Scientific Meeting 'Geotechnical Role to Accelerate Infrastructure Construction in Indonesia, Bidakarta Hotel Jakarta, November 15 - 162016 , pp. 77-82.

Hidayatullah, M. (2017) 'Perencanaan Dinding Penahan Tanah Tipe Kantilever dan Tipe Menyandar Pada STA $36+600$ Sampai Dengan STA36+650 Kecamatan Sebulu', eJournal Kurva S Jurnal Mahasiswa, 1(1), pp. 1-11.

Isya dna Sadat (2018) 'Analisis Efisiensi Dinding Penahan Tanah Type Kantilever di Kecamatan Babahrot Kabupaten Aceh Barat Daya', Jurnal Arsip Rekayasa Sipil dan Perencanaan 1, 1(1), pp. 18-26. doi: 10.24815/jarsp.v1i1.10331.
Khuzaifah, E. (2019) 'Studi tentang Dinding Penahan ( Retaining Wall )', Jurnal Swara Patra, 9(1), pp. 7-18.

Nasional, B. S. (2017) Persyaratan perancangan geoteknik.

Rahmad, R. and Nurman, A. (2018) 'Aplikasi SIG untuk Pemetaan Tingkat Ancaman Longsor di Kecamatan Sibolangit , Kabupaten Deli Serdang , Sumatera Utara', Majalah Geografi Indonesia, 32(1), pp. 1-13.

Ramia, I. N. (2017) 'Analisis Dinding Penahan Untuk Perkuatan Kelongsoran Lereng Di Jalan Bedugul Singaraja', Jurnal Matrix, 7(3), pp. 64-67.

Winanda RA, dan Setyanto, Y. M. H. (2017) 'Perencanaan Dinding Penahan Tanah Concrete Cantilever Dengan Menggunakan Program Plaxis (Studi Kasus : Jalan Liwa Simpang Gunung Kemala Krui KM. 264+600)', JRSDD, 5(4), pp. 1-13.

Wiraga, I. (2015) 'Penyebab Runtuhnya Dinding Penahan Tanah Pada Perumahan Karania Graha di Desa Jadi Kediri Tabanan', Jurnal Logic, 15(2), pp. 131-136. 